\title{
UTILIZATION OF HISTORICAL MAPS IN THE LAND USE CHANGE IMPACT STUDIES: A CASE STUDY FROM MYJAVA RIVER BASIN
}

\author{
P. VALENT ${ }^{1 *}$, P. RONČÁK' ${ }^{1}$, M. MALIARIKOVÁ', Š. BEHAN ${ }^{1}$
}

\section{Abstract}

The way land is used has a significant impact on many hydrological processes that determine the generation of flood runoff or soil erosion. Advancements in remote sensing which took place in the second half of the 20th century have led to the rise of a new research area focused on analyses of land use changes and their impact on hydrological processes. This study deals with an analysis of the changes in land use over a period of almost three centuries in the Myjava River catchment, which has an outlet at Šaštín-Stráže. In order to obtain information about the way the land was used in the past, three historical mappings representing various periods were used: the first (1st) military mapping (1764-1787), second (2nd) military mapping (1807-1869), and a military topographic mapping (1953-1957). The historical mappings have been manually vectorised in an ArcGIS environment to identify various land use categories. The historical evolution of land use was further compared with a concurrent land use mapping, which was undertaken in 2010 and exploited remote sensing techniques. The study also quantifies the impact of these changes on the long-term catchment runoff as well as their impact on flows induced by extreme precipitation events. This analysis was performed using the WetSpa distributed hydrological model, which enables the simulation of catchment runoff in a daily time step. The analysis showed that the selected catchment has undergone significant changes in land use, mainly characterized by massive deforestation at the end of the 18th century and land consolidation in the middle of the 20th century induced by communist collectivisation. The hydrological simulations demonstrated that the highest and lowest mean annual runoffs were simulated in the first (1st military mapping) and the last (concurrent land use monitoring) time intervals respectively with the smallest and largest percentages of forested areas.
Address

1 Department of Land and Water Resources Management, Faculty of Civil Engineering, Slovak University of Technology, Bratislava, Slovakia (peter_valent@stuba.sk, peter.roncak@ stuba.sk, marcela.maliarikova@stuba.sk)

* Corresponding author: peter_valent@stuba.sk

\section{Key words}

- Land use analysis,

- Historical maps,

- Vectorization,

- Rainfall-runoff modelling,

- WetSpa model. 


\section{INTRODUCTION}

The way and the intensity of which a landscape is changed and transformed from one state to another is determined by various natural and anthropogenic processes. While the natural processes are mainly characterized by gradual changes in the landscape attributes, such as the loss of natural vegetation due to changes in the climate, the anthropogenic processes are usually very fast and cause abrupt changes in these attributes. They often have a detrimental effect on the landscape's stability, biodiversity, and ecological services it could provide. Some of the examples of anthropogenic processes which have the most significant impact on transforming a landscape are agriculture, forestry, the construction of urban areas, and the transport infrastructure as well as water management, which extensively influences the character of riparian areas and ecosystems (Goudie, 2013). The intensity and extent of some anthropogenic processes can result in increasing the frequency of flood occurrences (including flash floods), increasing the extent of soil erosion processes from large agricultural fields and deforested areas as well as shortening the amount of time water stays in a catchment, thereby leading to a reduction of its retention capacity (GWP CEE, 2015). The effect of these anthropogenic processes on the way a landscape is used and the way it serves our needs is further multiplied by climate change, which has already proved to have a strong negative impact on water resources in our catchments (Szolgay et al., 2015; Szolgay and Hlavčová, 2000; Hlavčová et al., (2015 a,b); Kullman et al., 1995).

The previous paragraph illustrates how the way land is used can influence the runoff and erosion processes in a catchment. The origins of land use mapping dates to the beginning of the $20^{\text {th }}$ century in the United Kingdom, when Professor Dudley L. Stamp compiled The Land Utilisation Survey of Great Britain (1931). Within this work he managed to create maps of all of Great Britain and identified six land use types. The results of his work initiated efforts to conduct similar work worldwide. In Slovakia the first work trying to provide information about the spatial variability of land use types was undertaken by Kubijovyč (1932).

New methods, which mainly utilized remote sensing techniques, enabled researchers to obtain large amounts of land cover data with high spatial and temporal resolutions. Collecting, processing and analysing this data became a very active area of research that provided scientifically and practically relevant results in many disciplines such as agriculture, ecology, forestry or water management. In water management and hydrology the research is mainly focused on the effect of land use changes on runoff and erosion processes (see, e.g., Bruijnzeel, 2005; Burt and Slattery, 2005; Endreny, 2005; Goldman et al., 1986; He et al., 2013; Hlavčová et al., 2007; Li et al., 2013; Luce, 2005; Ray et al., 2010; Rončák and Hlavčová, 2014; Kohnová, 2015) as well as the dynamics of these changes over time (Butt et al., 2015; Lambin et al., 2003; RIKS BV, 2008; Verburg et al., 2002). A special category of studies analysing changes in land use over time deals with information from historical sources such as old maps, cadastres, land registers, and other historical documents. Analyses utilizing such information are frequently conducted in western countries with rich cartographical traditions (see, e.g., Baily, 2007; Bender et al., 2005; Cousins, 2001; Herold et al., 2016; Hirsch et al., 2016; Höhn, 2016; Leyk and Zimmerman, 2007; Skanes and Bunce, 1997). In Slovakia the pioneering work of Mazúr (1974) was later followed by others such as Behan (2016), Boltižar (2005), Drgoňa (2004), Maliariková (2015), Oláh (2009) and Valent et al. (2015). Since such information is relatively rare and is not available everywhere and from every time period, tasks aimed at assessments of impacts induced by land use changes are solely dependent on the availability of this information. From the aforementioned sources of information on past land use, historical maps are most common and most frequently used.
In hydrology and hydrological modelling, the last decades of the $20^{\text {th }}$ century brought about a massive development of complex hydrological models that enabled the simulation of the most relevant runoff creation and erosion processes (Szolgay, 2015). Some of these models, which belong to a group of spatially distributed models, take into account the effect of various land use types on the simulation of catchment runoff together with individual hydrological processes. Good examples of such models are the following: WetSpa (e.g., Wang et al., 1996; Rončák et al., 2014; Valent et al., 2015), FRIER (Horvát, 2008), SWAT (Arnold et al., 1998) and MIKE SHE (DHI, 1999; Im et al., 2009). Recently, these models have been extensively used to analyse the impact of the existing rapid changes in land use on the runoff from catchments (e.g., Hundecha and Bárdossy, 2004), the concentration of pollutants in rivers (e.g., Johnes, 1996), and the amounts of eroded material entering water bodies (e.g., Martinez-Murillo et al., 2011).

This paper presents the results of an analysis of land use changes over the last three centuries at a medium-sized catchment in Slovakia and assesses their impact on the total and extreme catchment runoff using a fully-distributed WetSpa rainfall-runoff model. The Myjava River catchment, with an outlet at the Šaštín-Stráže gauging station (Hydrological No. 1-4-13-03-073-01), which was selected for the analysis, is situated in the western part of Slovakia and has an area of $644.89 \mathrm{~km}^{2}$. The catchment has historically undergone significant changes in land cover and land use as the natural vegetation, which is mainly comprised of deciduous forests, has almost completely vanished for the sake of small agricultural plots, which were further aggregated into large fields during the communist collectivisation in the middle of the $20^{\text {th }}$ century. Nowadays, the catchment is characterized by an increased occurrence of floods (including flash floods), causing extensive soil erosion on large agricultural fields. The water erosion is responsible for the creation of gullies (Stankoviansky, 2001; 2003; Danáčová, 2015) and the contamination of water bodies with pollutants, which enter them together with transported material.

Information about the land utilization in the past was obtained from three historical maps from various periods, which were then compared to studies on the present state of the land use conducted in 2010. The historical maps came from the $1^{\text {st }}$ military mapping (1764$1787), 2^{\text {nd }}$ military mapping (1819-1858), and military topographic maps (1952-1957), which had to be georeferenced and manually vectorised to identify the individual land use types.

\section{HISTORICAL MAPS AS A SOURCE OF LAND USE INFORMATION}

Nowadays, at a time of massive advancements in remote sensing techniques and digitized and interactive mapping contents distributed over the internet, it might seem that historical maps do not have any meaningful use and are of no value any more, except artistically (Cajthaml, 2012). To the contrary, the new technologies have enabled the use of historic maps in entirely new ways, including various analyses and comparative studies.

The first efforts to document the way land is used in Slovakia was a cadastre consisting of cadastre maps and their documentation. The documentation provided information about individual parcels, including information as to how the parcels were used, while the maps enabled the location of the parcels spatially. A big disadvantage of this approach for tasks utilizing land use information is the fact that the borders of the individual parcels did not follow the borders of the land use types.

Another approach exploits historical maps, which could be considered as a significant source of information about the evolution of land over time. A big advantage of this approach is that the maps already contain some information about the land cover or the way in which the 
land has been used. The accuracy of these maps and the number of land use categories which can be identified mostly depend on the map scale, the precision of the cartographic techniques used, and the topic of the map. In our territory historical maps have mostly been created since the second half of the $18^{\text {th }}$ century for military purposes. An overview of the historical mappings on the territory of present-day Slovakia is given in the works of Labuda (2005), Zeman (2012), Cajthaml (2012), Maliariková (2015) and Behan (2016). In the study presented, three historical mappings and one current land use map were used to evenly cover three centuries of land use changes in the Myjava catchment. A simple description of the mappings is listed below:

\subsection{First military mapping (1764-1787)}

The experience gained from the Silesian Wars (the last Silesian War ended in 1763), during which military operations lacked any reliable topographic materials, inspired Empress Maria Theresa to commence work on the first systematic military mapping of the whole area of the Austro-Hungarian Empire (Zeman, 2012; Cajthaml, 2012). The work on the $1^{\text {st }}$ military mapping (I. MM) was initiated in 1764 and was finished after 23 years in 1785 during the reign of Joseph II (Zeman, 2012). The territory of present-day Slovakia was depicted on 267 map sheets on a scale of 1:28,800 (Porubská, 2012; Jakubík, 2012). The mapping was not based on any geodetic network, as the terrain relief and topography were usually estimated by military cartographs from the horse saddle (the "à la vue" method) or by using simple geodetic instruments such as a compass, astrolabe, sextant, or measuring table (Pokorný and Hájek, 2003). Some of the distances were also estimated by counting the revolutions of a carriage wheel or by counting the steps a cartographer made between two locations (Cajthaml, 2012). The relief of the maps was displayed using a rendering and hatching method without any other information about the terrain's elevation. The maps were finished in eight colours together with a legend and an accompanying document describing the basic characteristics of the selected territory (Jakubík, 2012). An example of a map section of the I. MM is displayed in Fig. 2a.

\subsection{Second military mapping (1807-1869)}

The lack of a geodetic network during the I. MM meant that by the beginning of the $19^{\text {th }}$ century, the maps were obsolete due to their unreliability and spatial inaccuracies. This led Emperor Francis I. (1792-1835) to order work to begin on a second military mapping (II. MM), which would significantly improve the accuracy of the I. MM and could be used to derive maps on smaller scales (Jakubík, 2012). The II. MM took advantage of a new trigonometric network, which was devised by Ludvik Augustin Fallon between the years 1806-1808 and 1810-1811 (Cajthaml, 2012). The work on the II. MM started in 1806 and finished after 64 years in 1869 (in Slovakia between 1819 and 1858). The II. MM employed the same scale as the I. MM $(1: 28,800)$ and used a Cassini-Soldner cartographic projection (Jakubík, 2012). The territory of present-day Slovakia was depicted on 260 map sheets which were similar, but not identical, to those in the I. MM. The maps were finished in 11 colours and utilized Lehman hatches to represent the terrain relief with denser hatching at higher altitudes. Despite the fact that it improved the representation of the relief, the map's readability worsened, mainly in areas with higher altitudes (Jakubík, 2012). The map was also supplemented by spot heights, which were related to the mean elevation of the Adriatic Sea at Trieste. Despite the fact that the II. MM was more accurate than the I. MM, the more than 60 years of its development (with frequent interruptions) had a negative impact on its uniformity and informa- tive value (some parts of the map were obsolete, while others were up to date). An example of a map section of the II. MM is displayed in Fig. 2b.

\subsection{Military topographic mapping (1953-1957)}

The third map series used in this work was a military topographic mapping on a scale of 1:25,000 (MTM25). Due to both WWII and the rapid political changes which took place at its end, there was no suitable mapping of Slovakia's territory after the war, which could be used for military purposes (Jakubík, 2012). The cartographic work on the MTM25 was initiated in 1953 and quickly finished in 1957. MTM25 is considered to be the first modern map series in our history; its degree of accuracy and content on a global scale are excellent. The maps utilized an S-52 coordinate system (based on the Krassovsky ellipsoid) and a Baltic Sea elevation system (see Mikšovský and Šídlo, 2001). The basic method used in the mapping was a universal photogrammetric method, which was applied to $70 \%$ of the area of the former Czechoslovakia. The rest of the country was mapped by other methods, which made use of older geodetic surveys which had been further revised. The MTM25 has been successfully applied in many areas such as the military, national economy, water management, sociology, and demography. After four major revisions, it was replaced by new mappings at the very end of the $20^{\text {th }}$ century. An example of a map section of the first series of the MTM25 is displayed in Fig. 2c.

\section{DIRECT MAPPING OF LAND USE}

The section above describes various sources of information (cadastre, historical maps, historical documents) about the way land has been used in previous decades or centuries. This way of obtaining land use information could be considered indirect, since the individual land use types have to be manually identified from maps which were mostly created for military purposes (see Ot'ahel' and Feranec, 2006). In the past the direct mapping of land use was only conducted on very large scales such as maps of urbanized areas, national parks or certain provinces; thus their use in analyses of land use changes over larger areas has been negligible. The direct systematic monitoring of the land cover of larger areas could be dated back to the 1970s, when the Landsat 1 satellite was placed into orbit (originally called ERTS 1 - Earth Resources Technology Satellite 1). Since 2013, the eight generation of Landsat satellites has been continuously retrieving medium resolution images $(30 \mathrm{~m})$ of land cover from 11 spectral bands (two of them are infrared). Nowadays, the land cover is being remotely monitored by multiple satellites such as QuickBird, SPOT 5, Ikonos, and SENTINEL-2m, which give resolutions as high as $0.61 \mathrm{~m}$ (the QuickBird satellite). The continuous supply of the high-resolution images on these instruments means that their analysis is currently one of the most active areas in environmental and geoscience research (see, e.g., Belward and Skøien, 2015; Hansen and Loveland, 2012; Feranec et al., 2016).

In this paper adjusted data from the CORINE land cover (CLC) inventory were used to compare the concurrent and historical utilization of land covers. CLC was originally initiated in 1985 to monitor the land cover of the European countries involved. Since then, four CLC monitorings have already been completed, which represent the following periods: 1990, 2000, 2006 and 2012. CLC distinguishes between 44 land cover classes with a minimum mapping unit of $100 \mathrm{~m}$. The CLC data used in the study presented represents the land cover in 2006. This data was further adjusted and supplemented with land use data obtained with a method of aerial photography (which was monitoring for the creation of ZB GIS) and land use data from the National Forest Centre in Zvolen. These three sources of land use data were 


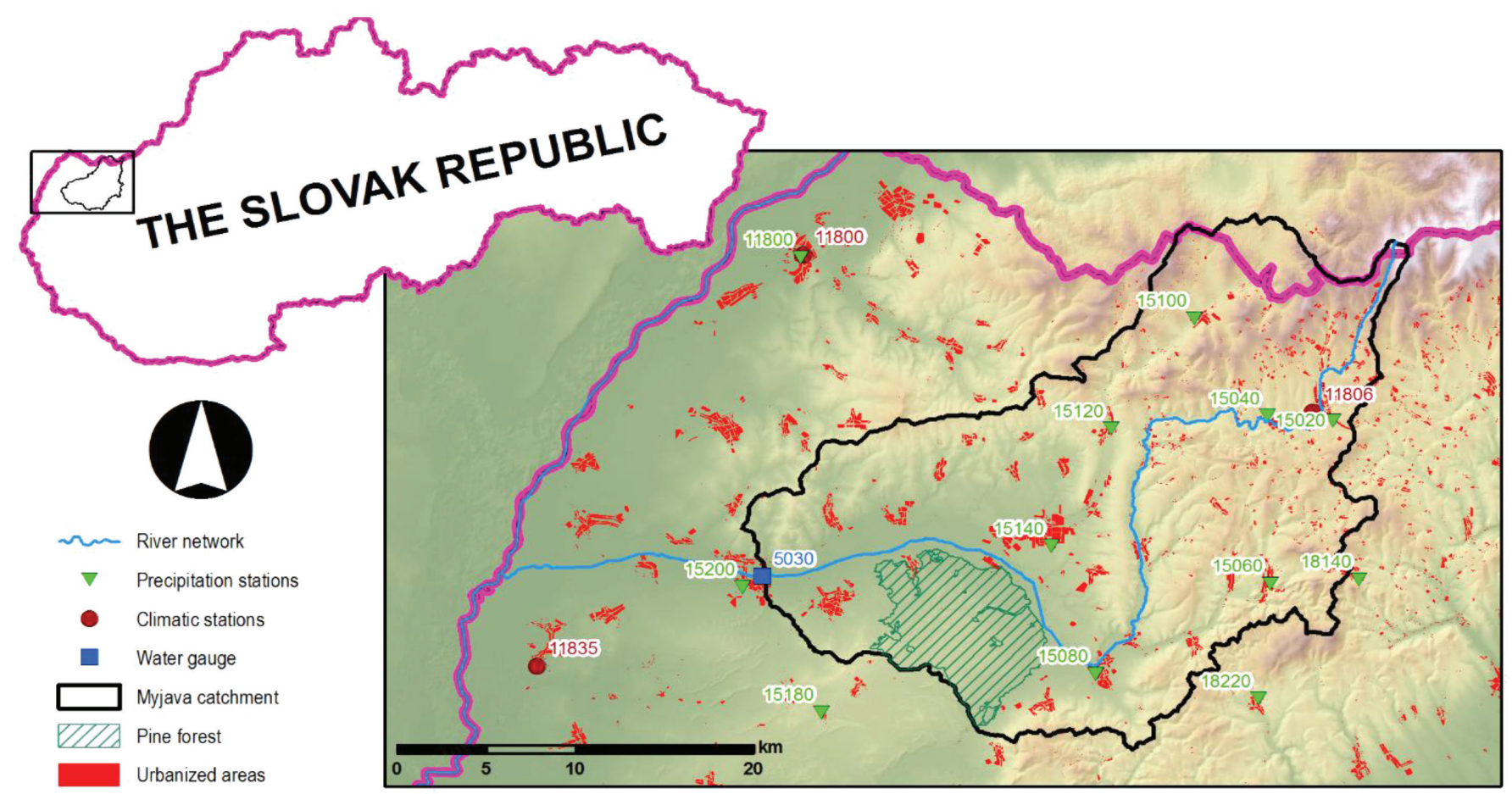

Fig. 1: The location of the Myjava River catchment within Slovakia. The larger image displays the 12 precipitation stations, 3 climatic stations and water gauge which were used in the rainfall-runoff modelling as well as the position of the large pine forest situated in the southern part of the catchment.

combined to create a unique land use map of the Myjava catchment that represents the period of 2010 (created by ESPRIT). An example of the 2010 land use monitoring (LU2010) is displayed in Fig. 2d.

\section{THE CASE STUDY FROM MYJAVA}

The impacts of the land use changes on a catchment runoff regime over a period of almost three centuries was assessed in a case study of the Myjava River catchment. The catchment's outlet is the water gauge at Šaštín-Stráže with hydrological No. 1-4-13-03-07301 and delineates a watershed of $644.89 \mathrm{~km}^{2}$. The catchment itself is situated in the western part of Slovakia and encompasses the geomorphological units of the Myjava Hill Land, Chvojnica Hill Land and the northern part of the Bor Lowlands (see Fig. 1). Most of the slopes of the catchment are oriented towards the south and southwest, which determine the direction of the river flow. The mean altitude of the catchment is $298 \mathrm{~m}$ a.s.l. with the highest point at $818 \mathrm{~m}$ a.s. 1 . (Čupec) and the lowest at $164 \mathrm{~m}$ a.s.l. (catchment outlet). The geological structure is mainly formed by sandstone and claystone with small patches of limestone situated in the northern part of the watershed. Most of the catchment lies in warm and moderately warm regions with a mean annual air temperature of $9{ }^{\circ} \mathrm{C}$ and a mean annual precipitation amount between 550 and $700 \mathrm{~mm}$ (in the northern parts, as much as $900 \mathrm{~mm}$ ). The potential natural vegetation is mainly represented by oak and hornbeam forests with the exception of sand-dune grasslands in the southern parts of the catchment covered with pine forests (Landscape Atlas of the Slovak Republic, 2002; Žarnovičan, 2008).

The current state of the watershed is significantly influenced by an intensive colonisation, the first stage of which took place in the second half of the $13^{\text {th }}$ century (Stankoviansky, 1997). The settlement of the area was accompanied by a rapid deforestation in favour of gaining new agricultural land, pastures and meadows. The second stage of the settlement was characterized by a so-called "kopanitze" colonisation and took place in the $17^{\text {th }}$ and $18^{\text {th }}$ centuries (Horváth, 1979). At this stage even the remote regions of the Myjava Hill Land were colonised by individual settlements of foresters, lumberjacks and sawyers. This period was accompanied by further deforestation, which resulted historically in the lowest percentages of forested areas at the end of the $18^{\text {th }}$ century. The gradual loss of the forests attracted the settlers to farm on the areas acquired, which led to the creation of the typical land use pattern known from the first half of the $20^{\text {th }}$ century (Stankoviansky, 2003). This pattern was characterized by a dense network of tiny hamlets irregularly dispersed with a mosaic of small and narrow plots, which were predominantly tilled along contour lines. The boundaries of these plots were formed by various linear elements such as access roads, paths, stone walls, terraces or drainage furrows, which slowed the runoff and acted as natural erosion mitigation measures. During the $19^{\text {th }}$ century there was an effort to restore some of the deforested areas that were unused. However, the biggest change in the way the country was used came after the end of WWII, when the communist regime initiated the collectivization of formerly small private plots into large cooperative fields. Even though the collectivization resulted in a further afforestation of areas which could not be accessed by machinery, the loss of the typical artificial linear landscape elements, along with bad agricultural practices, increased the occurrence of flash floods and significantly intensified erosion processes (Stankoviansky, 2001).

For the purpose of modelling the impact of the land use changes on the catchment runoff, hydrometeorological (flows and precipitation) and climate (air temperatures) data in a daily time step were used. The precipitation and air temperature data used came from selected stations situated within the catchment or in its near vicinity (see Fig. 1). The data available for the analysis spanned the period between 1997 and 2010 and were used in the simulation of the catchment runoff and other hydrological characteristics under four land use scenarios (I. MM, II. MM, MTP25 and LU2010). 


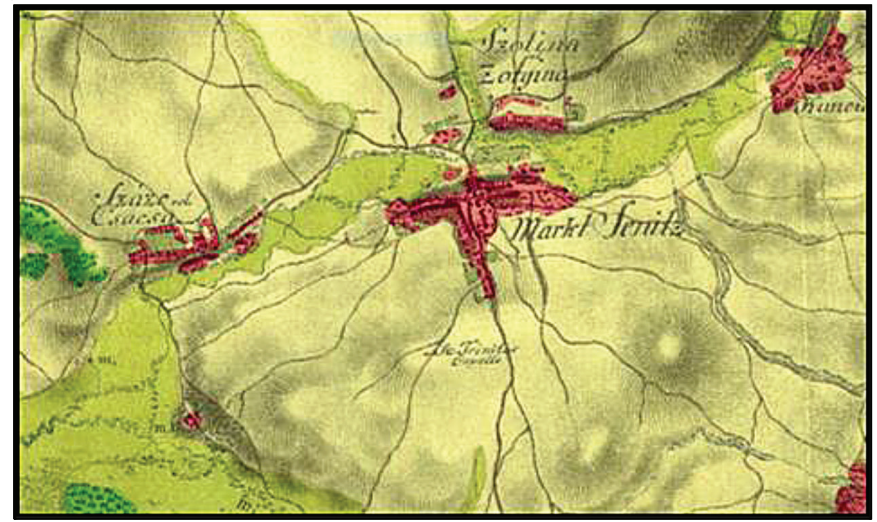

a)

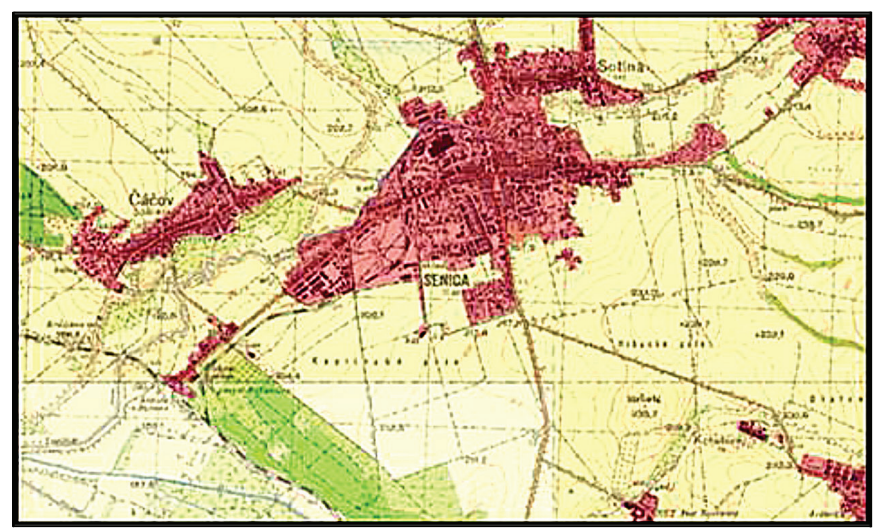

c)

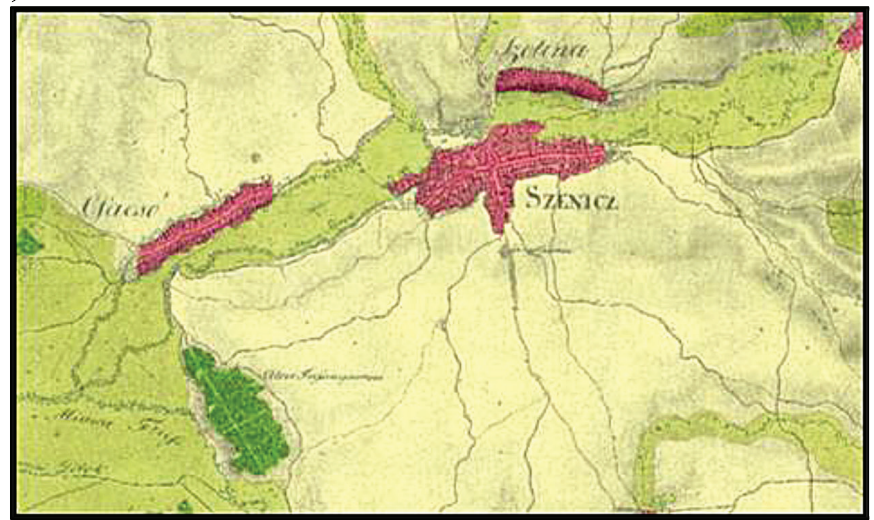

b)

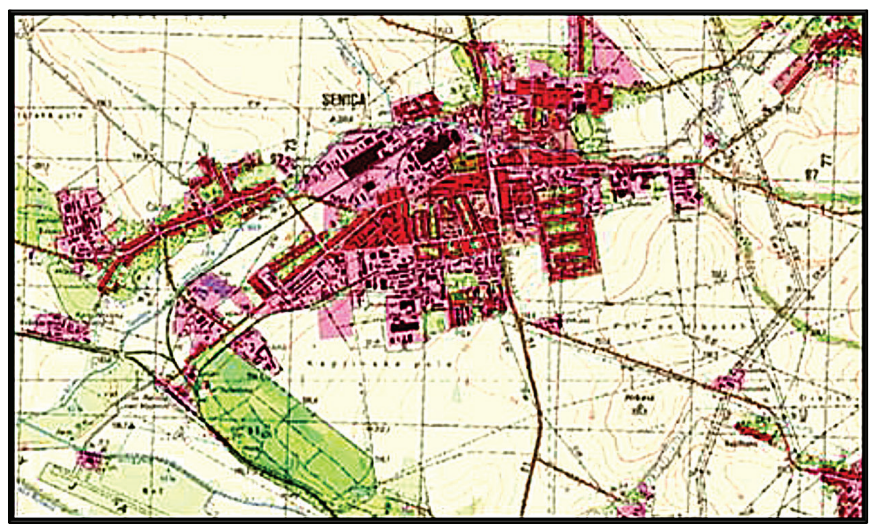

d)

Fig. 2: The historical mappings used in the study which display the territory of today's town of Senica: 1st military mapping (a), 2nd military mapping (b), military topographic mapping (c) and a map of concurent land use based on CORINE land cover monitoring (d). The maps also display a transparent layer of the land use types identified (the red areas correspond to urban areas). See the map of concurrent land use (d) for green urban areas within the town of Senica and compare it with the map from the military topographic mapping (c), where these could not be identified.

\section{METHODS}

\subsection{Vectorization of the historical maps}

The historical maps which were used in this study were available in the form of georeferenced raster images. The process of converting historical map lists into a raster format (scanning) and their subsequent georeferencing is thoroughly described in the work of Cajthaml (2012). After the historical maps are digitized and georeferenced, they still do not contain any explicit information about the way land is used. Before using these maps in analyses of land use changes, the individual types of land use together with their boundaries have to be identified and saved into a vector file format. This process is also known as "vectorization" and is usually carried out using GIS software. Despite the fact that nowadays there are numerous techniques that enable automatic vectorization (see, e.g., Chiang et al., 2014; Baily, 2007), the character of the historical maps (the ambiguity of land use type borders) prevented us from using any of them. Instead, the maps were vectorised using a manual vectorization technique, which is very slow but reliable and accurate (Cajthaml and Krejčí, 2008). Using this technique, the individual types of land use and their respective boundaries are manually identified, which brings about a certain amount of uncertainty into the process. Within this study the vectorization was a two-step process. In the first step the types of land use which could be identified from the map using a map key were vectorised. In the next step any areas which could not be assigned to any of the previously identified categories were assigned to arable land (the predominant type of land use in the catchment with no special map key). Due to the various complexities of the historical maps selected, a number of land use categories were identified. More on the manual vectorization of historical maps is given in the works of Velhartický (2009), Maliariková (2015), Behan (2016) and Valent et al. (2015).

\subsection{Analysis of land use changes}

The analysis of the land use changes in the Myjava River catchment was performed on the types of land use identified in three historical mappings (I. MM, II. MM, MTM25) and a current map of land use (LU2010). The analysis was comprised of a comparison of the percentages of the individual land use types in the total area of the catchment. Such an analysis only gave us information about the contingent total increase or decrease of the particular land use type within the selected time periods represented by the various mappings. The various complexities of the mappings analysed meant that it was not possible to identify the same number of land use types in all of them. Since this would not enable us to perform the analysis described above, the land use types identified had to be classified into the four classes which were present in each mapping. 


\subsection{Rainfall-runoff modelling}

In this study the modelling of the rainfall-runoff relationship was undertaken in order to assess the impact of land use changes on the long-term and extreme runoff from the Myjava catchment. Such an analysis requires the utilization of a distributed hydrological model, which would take into account the effects of land use on the runoff-generating processes. For this purpose the WetSpa distributed rainfall-runoff model was used. WetSpa is a physically-based and distributed hydrological model for predicting the water and energy transfer between soil, plants and the atmosphere on regional or basin scales and daily time steps; it was developed at the Vrije Universiteit Brussel, Belgium (see, e.g., Wang et al., 1996; Batelaan et al., 1996; Liu and De Smed, 2004). The model conceptualizes a hydrological basin system composed of the atmosphere, the canopy, and the root, transmission, and saturation zones. A basin is divided into a number of grid cells in order to deal with any heterogeneity. Each cell is further divided into the bare soil and vegetated parts, for which the water and energy balance are maintained. Apart from direct measurements of hydrometeorological and climatic variables, the model also exploits spatially distributed data such as the digital elevation model, map of soil types and map of land use types. These are used to estimate various spatially distributed parameters such as the depth of the root zone, Manning's roughness coefficient, soil porosity, the wilting point, flow accumulation, etc. (for a complete list of the spatially distributed parameters estimated, see Liu and De Smed (2004)). The model also contain 12 global parameters, which are constant for a whole catchment. The values of these parameters were optimized in the process of calibrating the model by utilizing a shuffled complex evolution algorithm (SCE) (Duan et al., 1993). The SCE algorithm maximized the Nash-Sutcliffe efficiency criterion (NSE) (Nash and Sutcliffe, 1970), which evaluates the goodness of fit between the observed and simulated flows (a perfect fit corresponds to a NSE value of 1 and a good fit to values above 0.5 ).

\section{RESULTS AND DISCUSSION}

\subsection{Analysis of land use changes}

The manual vectorization of the historical maps from the three time horizons (I. MM, II. MM, MTM25) resulted in the identification of various number of land use types. The different number of land use types identified were the result of the varying details and scales of the maps. In the case of the maps from the I. MM, only four types of land use were identified. The more detailed elaboration of the maps from the II. MM resulted in an additional type of land use which could be identified (transitional woodland shrubs), when compared to the maps from the I. MM. The drifting sands situated in the southern part of the catchment have been inhospitable for other types of forests except for those forests comprised of pines since the $17^{\text {th }}$ century, when mixed pine-oak forests receded into the northern parts of the catchment (Kubíček and Kanka, 2015). Based on this information the large forest situated in the southern part of the catchment was assigned to the "coniferous forest" type of land use in the cases of both I. MM and II. MM, even though the detail of these mappings did not permit distinguishing between various types of forests. Another improvement in the number of land use types identified came with the MTM25, which additionally distinguished between three different types of forested areas (coniferous, broad-leaved and mixed forests). The highest level of detail was provided by the current land use mapping (LU2010), with as many as nine types of land use identified (see Tab. 1). The percentage of the individual land use types, which was calculated for each mapping, on the total area of the catchment is listed in Tab. 1. The various amounts of the types of land use identified in the selected periods did not enable the performance of a direct analysis of the changes in utilization of the land. For instance, the class of transitional woodland shrubs was not present in I. MM; the bare land and water body classes were only present in LU2010; and the distinction between the three types of forests was only available for two out of the four mappings (MTM25 and LU2010).

In general, the types of land use which were the easiest to identify were comprised of urbanized areas and forests (without distinguishing the types of forest). In the case of the MTM25, it was also possible to reliably identify and delineate areas with natural grasslands and transitional woodland shrubs. These areas were invariably situated near forests where, especially in the higher parts of the catchment, the forests were gradually transformed into shrubs and further into natural grasslands. A closer look at Tab. 1 reveals that even though the percentages of the natural grassland type of land use differ within the individual mappings (between $8.9 \%$ and $15.1 \%$ ), together with transitional woodland shrubs, they are relatively stable in three out of the four mappings (with the small exception of II. MM). This might indicate that in the case of the I. MM, where the detail of the maps did not enable us to identify the transitional woodland shrub type of land use, it was already a part of the natural grasslands type of land use.

The remaining types of land use, which were only present in the case of the concurrent mapping (LU2010) and were comprised of bare land, water bodies and wetlands, had a negligible area (a total of only $0.4 \%$ ) (see Tab. 1). This enabled us to further classify the land use types identified into four main categories, which were present in all the mappings. The categories were represented as: 1) arable land, 2) urbanized areas, 3) forests (encompassing two types of forest in the case of I. MM and II. MM and three types in the case of MTM25 and LU2010), and 4) other areas with the most dominant land use types of natural grasslands and transitional woodland shrubs. This classification using the same classes available in all of the four mappings enabled us to directly compare the changes in land utilization which have taken place in the catchment for the almost four centuries of the intensive transformation of the natural landscape into an artificial one. The results of the analysis are displayed in Fig. 3 and indicate that the most significant changes were observed in the cases of arable land and forests. This corresponds to the description of the historical development of the catchment given in section 4, where it has been possible to observe a gradual decrease in the area of arable land and an increase in the area of forests (see Fig. 3) caused by the afforestation of the hardly cultivated upper parts of the catchment (Stankoviansky, 1997). In the case of the arable land, the decrease in the percentage from the total area of the catchment was from $61.7 \%$ during I. MM to only $44.7 \%$ during LU2010 with no changes between II. MM and MTM25 (54\%). On the other hand, the increase in the area of the forests achieved values between $21.8 \%$ during I. MM and 34.2\% during LU2010 with a gradual increase within these periods (see Fig. 3). By comparing the changes in the percentage of urbanized areas from the total size of the catchment, one can observe unusual behaviour, when it rises from $2.7 \%$ to $5.4 \%$ between I. MM and MTM25 and then falls again to $4.5 \%$ in LU2010. This could be explained by the fact that while in the case of historical maps, it was not possible to precisely distinguish between artificial surfaces and green urban areas (delineated by following the outer boundaries of the settlements), the more detailed LU2010 mapping did not include them in the urbanized areas (compare Fig. 2c and Fig. 2d). Similar behaviour can also be observed in the case of the "others" category, where it was particularly difficult to properly identify the natural grasslands and transitional woodland shrub types of land use in the cases of I. MM and II. MM. 
Tab. 1: Percentage of the area of the land use types identified on the individual historical and concurrent maps. The percentage is expressed as a percentage from the total catchment area. Due to the different amount of land use types identified, they were further classified into four categories: 1) arable land, 2) urbanized areas, 3) forests and 4) others.

\begin{tabular}{|c|c|c|c|c|}
\hline Land use type & I. MM & II. MM & MTM25 & LU2010 \\
\hline Arable land & $61.7 \%$ & $54 \%$ & $54 \%$ & $44.7 \%$ \\
\hline Urbanized areas & $2.7 \%$ & $2.7 \%$ & $5.4 \%$ & $4.5 \%$ \\
\hline Coniferous forests & $9.6 \%$ & $9 \%$ & $11.5 \%$ & $9.3 \%$ \\
\hline Broad-leaf forests & $12.2 \%$ & $15.4 \%$ & $10.3 \%$ & $22.4 \%$ \\
\hline Mixed forests & - & - & $4.5 \%$ & $2.5 \%$ \\
\hline Natural grasslands & $13.8 \%$ & $15.1 \%$ & $8.9 \%$ & $12.7 \%$ \\
\hline Transitional woodland shrubs & - & $3.9 \%$ & $5.4 \%$ & $3.6 \%$ \\
\hline Bare land & - & - & - & $0.1 \%$ \\
\hline Water bodies & - & - & - & $0.3 \%$ \\
\hline Wetlands & - & - & - & $<0.1 \%$ \\
\hline
\end{tabular}

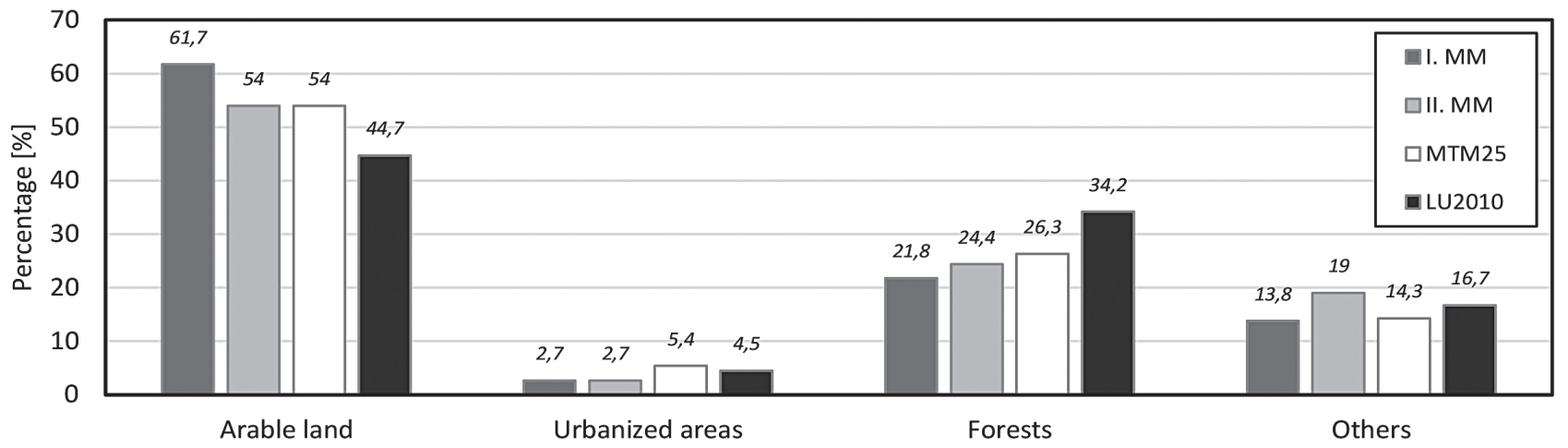

Fig. 3: Comparison of the percentage of land use categories from the total catchment area in the particular time intervals represented by various historical mappings (I. MM, II. MM, MTM25) and the concurrent map of land use (LU2010).

Despite these uncertainties in our assessment of the changes in the categories of "urbanized areas" and "others", the impact of these ambiguities on the catchment runoff is negligible due to their small areas. Since the biggest impact on the catchment runoff is associated with arable land and forests, which constitute the largest part of the catchment, it was possible to use the data to assess the impact of these changes on the catchment runoff.

\subsection{Assessment of the impact of land use changes on the catchment runoff}

The impact of land use changes on the long-term and short-term (extreme) catchment runoff was assessed using the WetSpa distributed rainfall-runoff model. The model enables the simulation of runoff from a catchment as well as other hydrological characteristics, while taking into account the way the land is used. Land use maps represent one of the main inputs into the model and are used to estimate various spatially distributed parameters of the model (i.e., interception parameters, root zone depths, list cover indices, surface roughness parameters). These parameters are not calibrated but are directly estimated from the land use map. The 12 global parameters of the model were calibrated on a dataset from 1.1.1997 to 31.12.2012. During the calibration process, the spatially distributed parameters derived from the land use map were estimated from the LU2010 concurrent mapping. The value of the Nash-Sutcliffe efficiency criterion that as- sessed the quality of the simulation was 0.611 , which represents an above average fit between the observed and simulated flows. The runoff from the catchment, which would have occurred in the previous time periods with different land utilization scenarios (I. MM, II. MM and MTM25), was simulated using the same dataset of hydrometeorological and climatic inputs and global parameters, but with different spatially distributed parameters, which were now estimated from a particular land use map.

In the first stage the WetSpa rainfall-runoff model was used to simulate the impact of the various land use scenarios on the long-term catchment runoff. Together with the mean annual long-term catchment runoff, another four characteristics of the hydrological regime (evapotranspiration and the surface, subsurface and base runoffs) were calculated. The results of the simulation are listed in Tab. 2, which provides additional information about the difference between the historical (I. MM, II. MM and MTM25) and current (LU2010) values of the total runoff and evapotranspiration. The simulations show that the lowest values of only $135.2 \mathrm{~mm}$ of the mean annual runoff occurred under the LU2010 scenario, which has the smallest areas of arable land and the largest areas of forests. Similar results can also be observed when utilizing the II. MM land use scenario with a $0.3 \mathrm{~mm}$ increase in the mean annual runoff values. The significant changes in the areas of arable land (an increase) and forests (a decrease), when compared to the values from the LU2010 scenario (see Tab. 1) as well as the decrease in the simulated values of the long-term mean annual evapotranspiration (a decrease of $2.8 \mathrm{~mm}$ per 
Tab. 2: Components of the hydrological balance obtained from the simulation of the catchment runoff under various land use scenarios. The last two columns represent the total difference in runoff and evapotranspiration between the individual historical and current land use scenarios.

\begin{tabular}{|c|c|c|c|c|c|c|c|}
\hline \multirow[b]{2}{*}{ Period } & \multirow{2}{*}{$\begin{array}{c}\text { Evapotranspiration } \\
{[\mathrm{mm}]}\end{array}$} & \multirow{2}{*}{$\begin{array}{c}\text { Surface runoff } \\
{[\mathrm{mm}]}\end{array}$} & \multirow{2}{*}{$\begin{array}{c}\text { Subsurface runoff } \\
{[\mathrm{mm}]}\end{array}$} & \multirow{2}{*}{$\begin{array}{c}\text { Base runoff } \\
{[\mathrm{mm}]}\end{array}$} & \multirow{2}{*}{$\begin{array}{l}\text { Total runoff } \\
{[\mathrm{mm}]}\end{array}$} & \multicolumn{2}{|c|}{ Difference } \\
\hline & & & & & & $\begin{array}{l}\text { Total runoff } \\
{[\mathrm{mm}]}\end{array}$ & $\begin{array}{l}\text { Evap } \\
{[\mathrm{mm}]}\end{array}$ \\
\hline I. MM & 544.2 & 2.0 & 28.9 & 106.2 & 137.1 & 1.9 & -3.8 \\
\hline II. MM & 545.2 & 1.9 & 29.4 & 104.2 & 135.5 & 0.3 & -2.8 \\
\hline MTM25 & 545.8 & 2.0 & 28.9 & 106.6 & 137.5 & 2.3 & -2.2 \\
\hline LU2010 & 548.0 & 3.5 & 29.3 & 102.4 & 135.2 & 0.0 & 0.0 \\
\hline
\end{tabular}

year on average), would suggest that the difference between the mean annual runoff under the II. MM and the LU2010 scenarios should be more significant. In order to explain such a small difference, one must compare the areas of the remaining categories. Tab. 1 reveals that the II. MM scenario has the highest percentage of natural grasslands among all the land use scenarios, which might indicate their strong impact on the simulation of catchment runoff (higher values resulting in smaller values of the catchment runoff). The highest values of the mean annual runoff $(137.5 \mathrm{~mm})$ were simulated under the MTM25 scenario, which is characterized by similar percentages of arable land and forests (an increase of 1.9\%) compared to the II. MM scenario. The MTM25 scenario also retained the highest percentage of urbanized areas and the lowest percentage of natural grasslands, which supports a hypothesis of its strong impact on the runoff simulations (lower values resulting in higher values of the catchment runoff). The results of the simulations under the I. MM scenario delivered the second largest value of the mean annual runoff (after the MTM25 scenario with the smallest percentage of natural grasslands) and the smallest values of the mean annual evapotranspiration. These results conform with the current understanding of the hydrological processes when a small percentage of forested areas results in small values of evapotranspiration, and a large percentage of arable land increases the total catchment runoff.

In the second stage the impact of land use on the simulation of extreme runoff was evaluated. For this evaluation, its impact on both summer and autumn floods was investigated. A summer flood was represented by an event from July 2001 and an autumn flood from November 1997. The hydrographs of the selected flood events under various land use scenarios are displayed in Fig. 4. In both flood events the impact of the various land use scenarios on the simulated peak flows is clearly visible and follows the same pattern with the highest peak flows simulated under the I. MM land use scenario followed by the II. MM, MTM25 and LU2010 scenarios. Fig. 4 suggests that the values of the simulated flood events are closely related to the percentages of arable land and forested areas in the specific land use scenarios. This argument is further supported by the small differences

a)

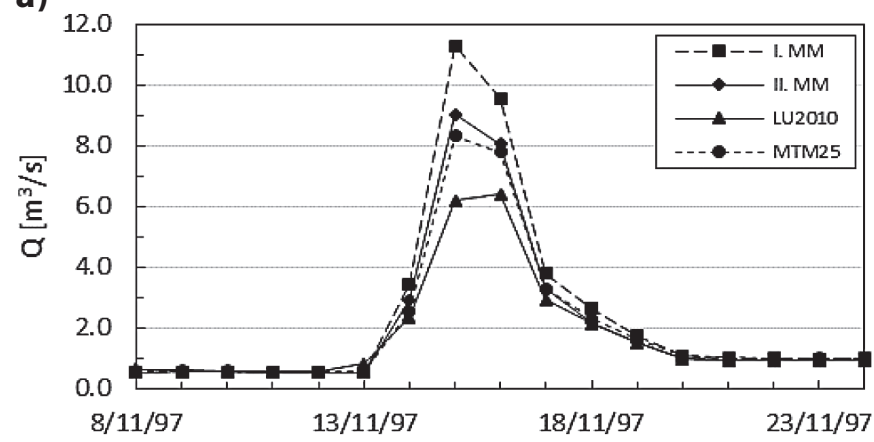

between the simulated peak flows under the II. MM and MTM25 scenarios (as opposed to the large differences between their simulated long-term catchment runoffs), which correspond to the very similar percentages of arable land (no difference) and forests (the MTM25 is higher by $1.9 \%$ ) observed in these scenarios.

\section{CONCLUSIONS}

The main objective of this study was to perform an assessment of the impact of the land use changes which took place in the River Myjava catchment over four centuries of intensive human activities on both long-term and short term (extreme) catchment runoffs. The information about the development of historical land use over the selected centuries was obtained from historical mappings, which took place on the territory of present-day Slovakia, and are comprised of a $1^{\text {st }}$ military mapping (1764-1787), a $2^{\text {nd }}$ military mapping (18071869), and a military topographic mapping (1953-1957). Information about the present state of the land use in the catchment was directly obtained from a vector map of the land use based on CORINE land cover monitoring (LU2010). The digitized and transformed analogue historical maps were vectorized in an ArcGIS environment in order to identify and delineate areas with identical types of land use. Due to the various levels of detail of the selected mappings, it was possible to identify four types of land use in the case of I. MM, five in the case of II. MM, and seven in the case of MTM25, compared to 11 types in the case of LU2010 (see Tab. 1). In order to quantify the changes in land use over the selected periods, the types of land use identified were further classified into four mutual categories.

The analysis of the changes in the percentages from the total area of the catchment showed that the greatest changes could be observed in the case of the arable land and forests categories. Fig. 3 indicates that the smallest percentage of forests was present in the I. MM maps, during the period of kopanitse colonization, when rapid deforestation took place (Stankoviansky, 1997). In the later periods the areas which could not be cultivated were gradually afforested, which conforms

b)

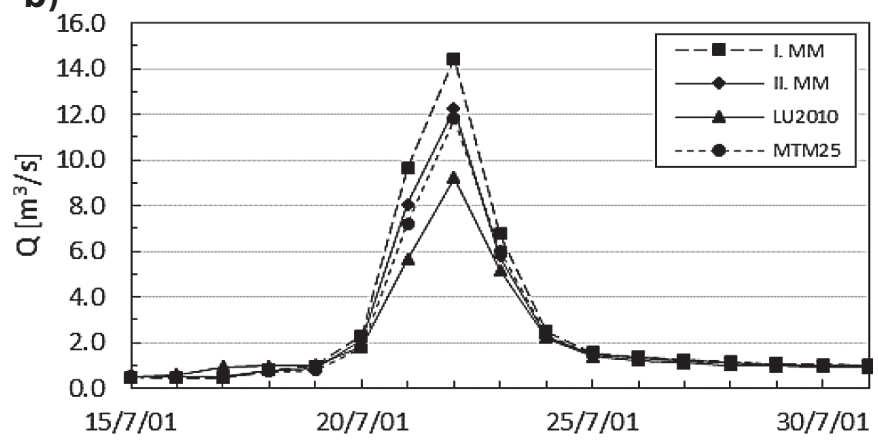

Fig. 4: Comparison of simulated mean daily flows under the various land use scenarios for selected a) autumn and b) summer flood events. 
with the findings of the analysis (see Fig. 3). On the other hand, one could witness a gradual decline in the case of arable land with the percentage from the total catchment area falling from as much as $61.7 \%$ (I. MM) to today's $44.7 \%$ (LU2010). The strange behavior in the reduction of urbanized areas between MTM25 and LU2010 (see Fig. 2) was explained by the inability of all the historical mappings to distinguish between green urban areas, versus the concurrent map of land use (LU2010), where it was possible (see Fig. 2).

The impact of the various land use scenarios on both long-term and extreme catchment runoff was evaluated using the WetSpa distributed rainfall-runoff model. In the first step the 12 global parameters of the model were estimated in a process of calibrating the model on a dataset spanning a period between 1 January 1997 and 31 December 2012. In the calibration process the concurrent land use scenario of LU2010 was used to estimate the spatially distributed model parameters. The goodness of fit of the model was evaluated by the Nash-Sutcliffe efficiency criterion, which gave a value of 0.611 , which represents an above-average fit between the observed and simulated flows.

The results of the assessment of the impact of various land use scenarios on the long-term catchment runoff and other components of the hydrological balance are displayed in Tab. 2. The simulations show that the highest values of the mean annual runoff were obtained under the I. MM scenario, while the lowest values were obtained under the LU2010 scenario (see Tab. 2). These results conform with the expectation that a higher percentage of arable land and a lower percentage of forested areas should result in higher values of the total catchment runoff. The analysis also revealed the strong impact of the natural grasslands type of land use on the long-term simulations of the mean annual runoff when a negligible difference in the percentages of arable land and forested areas in the cases of the II. MM and MTM25 scenarios and a substantial difference in the areas of natural grasslands resulted in a noticeable difference in the long-term simulations of the mean annual runoff (compare Tab. 1 and Tab. 2) (a part of the difference in the values of the mean annual runoff could also be explained by the higher percentage of the urbanized areas in the case of the MTM25 scenario).

The impact of the various land use scenarios on the extreme runoff was assessed on both selected summer and autumn flood events. In both events the highest values of the simulated peak flows were obtained under the I. MM scenario, followed by the II. MM, MTM25 and LU2010 (see Fig. 4) scenarios, which indicates a strong relation- ship between the percentages of arable land and forested areas and the extreme runoff. The simulations also revealed that the effect of the other types of land use (including the natural grasslands, which proved to have a strong impact on the simulation of the long-term mean annual runoff) on the simulation of the extreme runoff is not demonstrable.

The analysis of the impact of the land use scenarios on both longterm and extreme runoffs implies that the concurrent LU2010 scenario is the most favourable one in the light of reducing flood risks and retaining water on land. On the other hand, the simulations revealed that the worst runoff conditions were attained under the I. MM land use scenario with the highest values of both the long-term and extreme runoffs. Such results might be contrary to expectations, even though the total areas of arable land and forests are, in the case of I. MM, the most unfavourable ones among all the scenarios. During the period of the I. MM, the agricultural land was fragmented into a large number of small fields, which were often divided by balks, strips of vegetation, access to communications, pathway lynchets, or drainage furrows acting like significant surface runoff and erosion alleviation elements. The collectivization of agricultural land resulted in the merging of small plots of land and the removal of the dense network of these linear landscape elements as well as the levelling of terraces created by long-term contour tillage (which affected the MTM25 and LU2010 scenarios). These actions resulted in the creation of large blocks of agricultural fields. The runoff from these fields has higher velocities, which significantly increase erosion processes and fast runoff. This has resulted in the Myjava Hill Land being a part of the area with the highest density of permanent gullies in Slovakia (Stankoviansky, 2003). However, the rainfall-runoff modelling did not confirm the worsening of the runoff generation processes induced by these changes. This could be explained by the fact that the model used in the study is too coarse (the size of the grid cells is 100 by $100 \mathrm{~m}$ ) to take these measures into account as well as the various agricultural practices applied.

\section{Acknowledgements}

This work was supported by the EU-FP7 RECARE project under the 603498 project ID, the Slovak Research and Development Agency under the contract No. APVV-15-0497 and the Slovak Science Grant Agency under the contracts No. VEGA 1/0710/15. The authors thank the agency for its research support. 


\section{REFERENCES}

Arnold, J. G. - Srinivasan, R. - Muttiah, R. S. - Williams, J. R. (1998) Large area hydrologic modeling and assessment part I: Model development. Journal of the American Water Resources Association, 34(1), pp. 73-89.

Baily, B. (2007) The extraction of digital vector data from historic land use maps of Great Britain using image processing techniques. e-Perimetron, 2(4), pp. 209-223.

Batelaan, O. - Wang, Z. M. - De Smedt, F. (1996) An adaptive GIS toolbox for hydrological modelling. In: Kovar, K. - Nachtnebel, H.P. (eds.) Application of geographic information systems in hydrology and water resources management. IAHS Publ. No. 235, pp. 3-9.

Behan, Š. (2016) Analýza zmeny využitia územia a jej vplyv na odtok $z$ povodia (Analysis of land use changes and their impact on catchment runoff). Diploma thesis. Faculty of Civil Engineering, STU in Bratislava, Bratislava (in Slovak).

Belward, A. S. - Skøien, J. O. (2015) Who launched what, when and why; trends in global land-cover observation capacity from civilian earth observation satellites. ISPRS Journal of Photogrammetry and Remote Sensing, 103, pp. 115-128.

Bender, O. - Boehmenr, H. J. - Jens, D. - Schumacher, K .P. (2005) Analysis of land-use change in a sector of Upper Franconia (Bavaria, Germany) since 1850 using land register records. Landscape Ecology, 20, pp. 149-163.

Boltižiar, M. (2005) Tvorba historických máp krajinnej štruktúry Tatier na základe leteckých snimok a ich aplikácia pri hodnoteni zmien krajiny (Creation of the historical maps of landscape structure of the Tatras based on the aerial photogrammetry and their application in the land use change assessments). In: Pravda, J., (ed.) Historické mapy. Bratislava: Kartografická spoločnost' SR a Geografický ústav SAV, pp. 19-26 (in Slovak).

Bruijnzeel, L. S. (2005) Land Use and Land Cover Effects on Runoff Processes: Forest Harvesting and Road Construction. In: Anderson, M. G. (ed.) Encyclopedia of Hydrological Sciences. Wiley, Chichester, pp. 1813-1829.

Burt, T. P. - Slattery, M. (2006) Land Use and Land Cover Effects on Runoff Processes: Agricultural Effects. In: Anderson, M. G. (ed.) Encyclopedia of Hydrological Sciences. Wiley, Chichester, pp. 1804-1812.

Butt, A. - Shabbir, R. - Ahmad, S. S. - Aziz, N. (2015) Land use change mapping and analysis using Remote Sensing and GIS: A case study of Simly watershed, Islamabad, Pakistan. The Egyptian Journal of Remote Sensing and Space Science, 18(2), pp. 251-259.

Cajthaml, J. (2012) Analýza starých máp v digitálnom prostředí na př́kladu Můllerových map Čech a Moravy (Analysis of historical maps in a digital environment using an example of the Muller maps of Czechia and Moravia). Česká technika - nakladatelství ČVUT, Prague, p. 172 (in Czech).

Cajthaml, J. - Krejčí, J. (2008) Využití starých map pro výzkum krajiny (Usage of old maps for environmental research). GIS Ostrava 2008, Ostrava, 27.-30.1.2008, TANGER spol. s r.o., CD ROM (in Slovak).

Chiang, Y. - Leyk, S. - Knoblock, C. A. (2014) A survey of digital map processing techniques. ACM Computing Surveys, 47(1), p. 44.
Cousin, S. A. O. (2001) Analysis of land-cover transitions based on 17 th and 18th century cadastral maps and aerial photographs. Landscape Ecology, 16, pp. 41-54.

Danáčová, M. - Nosko, R. - Výleta, R. - Randusová, B. - Szolgay, J. (2015) Možnosti posúdenia zmien výmol’ovej erózie na povodi Myjavy (Possibilities of estimating the gully erosion changes on the Myjava basin). Acta hydrologica Slovaca, 16(thematic issue), pp. 167-175 (in Slovak).

DHI (Danish Hydraulic Institute) (1999) MIKE SHE water movement: user manual. Hørsholm, Denmark.

Drgoňa, V. (2004) Assessment of the landscape use changes in the city of Nitra. Ekológia, 23(3-4), pp. 385-392 (in Slovak).

Duan, Q. Y. - Gupta, V. K. - Sorooshian, S. (1993) Shuffled complex evolution approach for effective and efficient global minimization. Journal of Optimization Theory and Applications, 76(3), pp. 501-521.

Endreny, T. (2005) Land Use and Land Cover Effects on Runoff Processes: Urban and Suburban Development. In: Anderson, M. G. (ed.) Encyclopedia of Hydrological Sciences. Wiley, Chichester, pp. 1776-1803.

Feranec, J. - Soukup, T. - Hazeu, G. - Jaffrain, G. (2016) European Landscape Dynamics: CORINE Land Cover Data. CRC Press, Boca Raton, USA, p. 337.

GWP CEE (2015) Natural small water retention measures combining drought mitigation, flood protection and biodiversity conservation. Guidelines, Global Water Partnership Central and Eastern Europe.

Goldman S. J. - Jackson K. - Bursztynsky T. A. (1986) Erosion and Sediment Control Handbook. McGraw-Hill Book Co., New York.

Goudie, A. S. (2013) The Human Impact on the Natural Environment: Past, Present and Future (7th edition). Chichester, UK, Wiley-Blackwell, p. 424.

Hansen, M. C. - Loveland, T. R. (2012) A review of large area monitoring of land cover change using Landsat data. Remote Sensing of Environment, 122, pp. 66-74.

He, Y. - Lin, K. - Chen, X. (2013) Effect of Land Use and Climate Change on Runoff in the Dongjiang Basin of South China. Mathematical Problems in Engineering, 2013, p. 14.

Herold, H. - Hecht, R. - Meinel, G. (2016) Old maps for land use change monitoring. International Workshop on Exploring Old Maps (EOM 2016), University of Luxembourg, Maison du Savoir, Campus Belval, 8 June 2016.

Hirsch, T. - Westphal, F. - Saeger, K. - Schwotzer, T. (2016) Vectorization of old maps. International Workshop on Exploring Old Maps (EOM 2016), University of Luxembourg, Maison du Savoir, Campus Belval, 8 June 2016.

Hlavčová, K. - Szolgay, J. - Kohnová, S. - Kostka, Z. (2007) Využitie zrážkovo-odtokových modelov s priestorovo rozčlenenými parametrami pri odhade vplyvu využivania územia na odtokové procesy (Use of Distributed Rainfall-runoff Models for Estimation of the Land-use Impact on Runoff Regime in Basins). Životné Prostredie, 41(4), pp. 206-211 (in Slovak). 
Hlavčová, K. - Lapin, M. - Valent, P. - Szolgay, J. - Kohnová, S. - Rončák, P. (2015a) Estimation of the Impact of Climate Change-Induced Extreme Precipitation Events on Floods. Contributions to Geophysics and Geodesy, vol. 45, no. 3, pp. 173-192.

Hlavčová, K. - Kotríková, K. - Kohnová, S. - Valent, P. (2015b). Changes in the Snow Water Equivalent in Mountainous Basins in Slovakia Over Recent Decades. In: Proceedings of the International Association of Hydrological Sciences. Vol. 370, (2015), online, pp. 109-116. ISSN 2199-8981.

Höhn, W. (2016) Georeferencing, annotation, and analysis tools for old maps: an overview. International Workshop on Exploring Old Maps (EOM 2016), University of Luxembourg, Maison du Savoir, Campus Belval, 8 June 2016.

Horvát, O. (2008) Description of the rainfall-runoff model FRIER. Podzemná voda, 14(1), pp. 37-45.

Horváth, P. (1979) Vývoj kopaníc a kopaničiarskeho osídlenia v oblasti Myjavskej pahorkatiny do konca 18. storočia (Development of the kopanitse and kopanitse settlement in the region of the Myjava Hill Land till the end of the $18^{\text {th }}$ century), Historické štúdie, 23, pp. 87-170 (in Slovak).

Hundecha, Y. - Bárdossy, A. (2004) Modeling of the effect of land use changes on the runoff generation of a river basin through parameter regionalization of a watershed model. Journal of Hydrology, 1-4, pp. 281-295.

Im, S. - Kim, H. - Kim, C. - Jang, C. (2009) Assessing the impacts of land use changes on watershed hydrology using MIKE SHE. Environmental Geology, 57, pp. 231-239.

Jakubík, J. (2012) Vývoj vojenskej kartografie na území Slovenska (Development of military cartography in territory of Slovakia). Kartografické listy, 20(1), pp. 28-28 (in Slovak).

Johnes, P. J. (1996) Evaluation and management of the impact of land use change on the nitrogen and phosphorus load delivered to surface waters: the export coefficient modelling approach. Journal of Hydrology, 183(3), pp. 323-349.

Kohnová, S. - Karabová, B. - Hlavčová, K. (2015) On the Possibilities of Watershed Parameterization for Extreme Flow Estimation in Ungauged Basins. In: Proceedings of the International Association of Hydrological Sciences. Vol. 370, (2015), online, pp. 171-175. ISSN 2199-8981.

Kubíček, F. - Kanka, R. (2015) Lesy na viatych pieskoch Borskej nižiny (Forests of the eolitic sand dunes in the Bor Lowland), Available at: http://www.zahorskemuzeum.sk/lesy-na-viatychpieskoch-borskej-niziny/, (Accessed: 11. Nov. 2016) (in Slovak).

Kubijovyč, V. (1932) Rozšíření kultur a obyvatelstva v Severních Karpatech (The spread of cultures and inhabitants in the Northern Carpathians). Sborník Filosofické fakulty UK v Bratislave, 8(6063) (in Czech).

Kullman, E. - Slamka, I. - Gavurník, J. (1995) Hodnotenie vplyvu klimatických zmien na režim výdatnosti prameňov a predpokladaný dopad týchto klimatických zmien na disponibilné množstvá podzemných vôd (An assessment of the climate change impacts on the regime of spring yield and an expected impact of these changes on the available amounts of groundwater). Report for NKP SR. Department of Groundwater, Faculty of Natural Sciences, Comenius University, Bratislava.

Labuda, M. (2005) Identifikácia krajinných prvkov významných pre ekologickú stabilitu krajiny s využitim historických mapových diel (Identification of landscape elements significant for the ecological stability of land using historical map series). Geografické aspekty středoevropského prostoru, Brno: Masaryk University, pp. 555-563 (in Slovak).

Lambin, E. F. - Geist, H. J. - Lepers, E. (2003) Dynamics of landuse and land-cover change in tropical regions. Annual Review of Environment and Resources, 28, pp. 205-241.

Landscape Atlas of the Slovak Republic (2002) 1st ed., Bratislava: Ministry of the Environment of the Slovak Republic, Banská Bystrica: Slovak Environmental Agency, p. 344.

Leyk, S. - Zimmermann, N. E. (2007) Improving land change detection based on uncertain survey maps using fuzzy sets. Landscape Ecology, 22, pp. 257-272.

Li, L. - Wang, Y. - Liu, C. (2013) Effects of a land use changes on soil erosion in a fast developing area. International Journal Of Environmental Science and Technology, 11(6), pp. 1549-1562.

Liu, Y. B. - De Smedt, F. (2004) WetSpa Extension, A GIS-based Hydrologic Model for Flood Prediction and Watershed Management (Documentation and User manual). Vrije Universiteit Brussel, Brussels, Belgium, p. 126.

Luce, C. H. (2005) Land Use and Land Cover Effects on Runoff Processes: Fire. In: Anderson, M. G. (ed.) Encyclopedia of Hydrological Sciences, Wiley, Chichester, pp. 1830-1837.

Maliariková, M., (2015) Analýza využitia územia z historických máp na povodi Myjavy (Analysis of land use from the historical maps on the Myjava River basin). Diploma thesis. Faculty of Civil Engineering, SUT in Bratislava, Bratislava (in Slovak).

Martinez-Murillo, J. F. - López-Vicente, M. - Poesen, J. Ruiz-Sinoga, J. D. (2011) Modelling the effects of land use changes on runoff and soil erosion in two Mediterranean catchments with active gullies (South Spain). Landform Analysis, 17, pp. 99-104.

Mazúr, E. (1974) Využitie zeme (Land utilization). In: Plesník, P., et al. Slovensko. L'ud - 1. čast' (Slovakia. Nation - 1'st part), Bratislava: Obzor, pp. 75-100 (in Slovak).

Mikšovský, M. - Šídlo, B. (2001) Topografické mapování našeho území ve 20. století (Topographic mapping of our territory in the $20^{\text {th }}$ century). Available at: http://gis.zcu.cz/kartografie/konference2001/sbornik/miksovsky/miksovsky_referat.htm, (Accessed: 4. Oct. 2016) (in Slovak).

Nash, J.E. - Sutcliffe, J.V. (1970) River flow forecasting through conceptual models 1. A discussion of principles. Journal of Hydrology, 10(3), pp. 282-290.

Oláh, B. (2009) Historical maps and their application in landscape ecological research. Ekológia, 28(2), pp. 143-151.

Ot’ahel', J. - Feranec, J. (2006) Výskum a mapovanie využitia krajiny: minulost' a súčasnost'v kontexte Slovenska (Research and mapping of land use: the past and the present in the context of Slovakia). Geografický časopis, 58(2), pp. 105-123 (in Slovak).

Pokorný, M. - Hájek, M. (2003) Analýza priestorových objektov na mapách I. vojenského mapovania (Spatial objects analysis on the maps from the $1^{\text {st }}$ military mapping). Kartografické listy, 11, pp. 74-84 (in Slovak). 
Porubská, B. (2012) Mapy 1., 2. a 3. vojenského mapovania (Maps of the $1^{\text {st }}, 2^{\text {nd }}$ and $3^{\text {rd }}$ military mappings). Available at: http://www. pamiatky.sk/sk/page/mapy-1-2-3-vojenskeho-mapovania, (Accessed: 13. Sept. 2016) (in Slovak).

Ray, D. K. - Pielke Sr., R. A. - Nair, U. S., Niyogi, D. (2010) Roles of atmospheric and land surface data in dynamic regional downscaling. Journal of Geophysical Research, 115, D05102.

RIKS BV (2008) Assessment and scenarios of land use change in Europe [Report], Maastricht, The Netherlands, p. 82.

Rončák, P. - Hlavčová, K. (2014) Impact of changes in forest associations from the generation of runoff in the Myjava River basin. Catchment processes in regional hydrology: Confronting experiments and modeling in Carpathian drainage basins, Bratislava, Slovakia and Sopron, Hungary, 27. Oct. 2014.

Rončák, P. - Hlavčová, K. - Štefunková, Z. (2014) Posúdenie prenositel'nosti parametrov $v$ distribuovanom zrážkovo-odtokovom modeli (Transfer of parameters in a distributed rainfall-runoff model). Acta Hydrologica Slovaca, 15(1), pp. 196-193 (in Slovak).

Skanes, H. M. - Bunce, R. G. H. (1997) Directions of landscape change (1741-1993) in Virestad, Sweden - characterised by multivariate analysis. Landscape and Urban Planning, 38, pp. 61-75.

Stamp, D. (1931) The land utilization survey of Britain. Geographical Journal, 78, pp. 40-47.

Stankoviansky, M. (1997) Antropogénne zmeny krajiny myjavskej kopaničiarskej oblasti (Anthropogenic transformations of landscape in the Myjava kopanitse region). Životné Prostredie, 31, pp. 84-89 (in Slovak).

Stankoviansky, M. (2001) Erózia z orania a jej geomorfologický efekt s osobitým zretel'om na Myjavsko-Bielokarpatskú kopaničiarsku oblast' (Tillage erosion and its geomorphic effect with special regard to the Myjava-White Carpathian kopanitse area). Geografický časopis, 53(2), pp. 95-110 (in Slovak).

Stankoviansky, M. (2003) Historical evolution of permanent gullies in the Myjava Hill Land, Slovakia. Catena, 51, pp. 223-239.

Szolgay, J. (2015). Catchment and River Processes: Review of Experimental Research and Mathematical Modeling in Hydrology in Slovakia from 2011 to 2014. In: Contributions to Geophysics and Geodesy : Geodesy and Geophysics in Slovakia 2011-2014. $26^{\text {th }}$ General Assembly of IUGG. Prague, ČR, 22. 6. - 2. 7. 2015. Vol. 45, special issue (2015), pp. 39-55. ISSN 1335-2806.
Szolgay, J. - Hlavčová, K. (2000) Modelové riešenie odhadov vplyvu zmeny klímy na hydrologický cyklus a vodné hospodárstvo Slovenska (Modeling of climate change impact on hydrological cycle and water resources management in Slovakia). Životné Prostredie, 34(2), pp. 75-80 (in Slovak)

Szolgay, J. - Hlavčová, K. - Kohnová, S. - Čistý, M. - Danáčová, M. - Valent, P. - Výleta, R. (2015) Analýza a zhodnotenie hydrologickej bilancie na toku Parná a vodohospodárskej sústavy nádrže Horné Orešany (Analysis and assessment of the hydrological balance at the River Parná and the water management system of the Horné Orešany reservoir). Report for Amylum Slovakia. Department of Land and Water Resources Management, Faculty of Civil Engineering, SUT Bratislava (in Slovak).

Valent, P. - Maliariková, M. - Rončák, P. - Hlavčová, K. Karabová, B. (2015) Analýza zmeny spôsobu využitia územia z historických máp na povodí Myjavy (Analysis of land use changes in the Myjava River basin utilizing historical maps). Acta Hydrologica Slovaca, 16(Thematic issue), pp. 3-14 (in Slovak).

Velhartický, D. (2009) Návod pro vektorizaci map třetího vojenského mapováni (Methodology for the vectorization of the third military mapping maps). Thesis. University of West Bohemia, Plzen (in Czech).

Verburg, P. H. - Soepboer, W. - Veldkamp, A. - Limpiada, R. Espaldon, V. (2002) Modeling the Spatial Dynamics of Regional Land Use: The CLUE-S Model. Environmental Management, 30(3), pp. 391-405.

Wang, Z. - Batellan, O. - De Smedt, F. (1996) A Distributed Model For Water And Energy Transfer Between Soil, Plants And Atmosphere (Wetspa). Physics and Chemistry of the Earth, 21, pp. 189-193.

Žarnovičan, H. (2008) Lesné spoločenstvá východnej časti Myjavskej pahorkatiny (Forest communities in the eastern part of the Myjavská pahorkatina hilly country). Phytopedon, 7(2), pp. 230-239 (in Slovak).

Zeman, M. (2012) Historické mapové diela na geoportal.sazp.sk (Historical map series at geoportal.sazp.sk). Enviromagazín, 5, pp. 20-21 (in Slovak). 